\title{
Arab Voices in Western Writing: The Politics of the Arabic Novel in English and the Anglophone Arab Novel
}

\section{Geoffrey Nash}

\section{CpenEdition}

\section{Journals}

Electronic version

URL: https://journals.openedition.org/ces/4603

DOI: $10.4000 /$ ces.4603

ISSN: 2534-6695

\section{Publisher}

SEPC (Société d'études des pays du Commonwealth)

\section{Printed version}

Date of publication: 1 April 2017

Number of pages: $27-37$

ISSN: 2270-0633

\section{Electronic reference}

Geoffrey Nash, "Arab Voices in Western Writing: The Politics of the Arabic Novel in English and the Anglophone Arab Novel", Commonwealth Essays and Studies [Online], 39.2 | 2017, Online since 03 April 2021, connection on 04 June 2021. URL: http://journals.openedition.org/ces/4603 ; DOI: https:// doi.org/10.4000/ces.4603

\section{(c) (i) $\ominus$}

Commonwealth Essays and Studies is licensed under a Licence Creative Commons Attribution - Pas d'Utilisation Commerciale - Pas de Modification 4.0 International. 


\section{Arab Voices in Western Writing: The Politics of the Arabic Novel in English and the Anglophone Arab Novel}

This article discusses the problems faced by Arab writers who wish to have their work taken up by Western publishing houses. It starts out from the assumption that, in the main, the latter demand reproduction of a specific repertoire of representations and images of Arabs. Arab authors - whether their writings are translated from Arabic or inscribed directly in western languages - have the option of acculturating to these requirements or run the risk of not getting into print. The article tests claims often made for Anglophone Arab novels that they are a form of postcolonial writing with both the potential and the achievement of circumventing translational bias and undermining stereotyping of Arabs and Islam.

In the twenty-first century translation from English into other languages massively outweighs translation of other languages into English. "Only three per cent of all books published in English are translated from foreign languages, and within this group translations from Arabic represent the weakest of the weak" (Abou-Ela 42). Nonetheless, given the pressures of gaining a name as an author of Arabic literature, not to speak of the poor rewards, it is not surprising that some Arab writers might seek to buck that trend and, however forbidding the challenge, eye the opportunities translation might bring. What are the problems that face Arab writers who wish to see their work translated? A recent (2015) call for papers by Clina, an interdisciplinary journal of translation published in Spain, proposed for consideration a number of issues ranging from: "the factors that influence the selection of an Arabic literary work for translation"; whether "translators foreground, or exaggerate, particular stylistic or thematic aspects in the works they translate"; whether the notion that it is "embargoed" still influences the way Arabic literature is being treated by translators, publishers and readers; and whether there is a deliberate intent, as Said stated, to "interdict any attention to texts that do not reiterate the usual clichés about 'Islam,' violence, sensuality and so forth?” (Shamma) A consensus among critics and commentators concerning the obstacles facing the Arabic novel in Western markets and issues surrounding translation of Arabic literary texts into English/French might be summarized as: 1) The Western point of view that Arabic literature is "problematic" and is still therefore to some degree "embargoed," for the reason that Said gave in 1990: that "Arabs and their language were somehow not respectable, and consequently dangerous, louche, unapproachable." 2) The limited criteria that determine which type of text gets translated and which does not. 3) The quality of translations produced (these frequently being sub-standard).

The set of conditions just discussed imposes on the writer in Arabic who wants her/ his work translated the requirement of recognizing differences in implied readerships and negotiating the putative gap between the global and the local. Even before this process can begin, however, s/he must face the more basic problem of finding her/ himself caught somewhere between the two: what Samia Mehrez considers the double bind of contemporary Egyptian writers "unable to manoeuvre freely within the [local] literary cultural field because of the influence of the state on the cultural establishment and locked out [...] in the global literary field" (qtd. in Naaman 451). A live issue at the 
heart of debates within World Literature, this situation also links to conditions closely tied in with the international publishing industry. Speaking of a category of Arabic fiction which he terms "the Arabic bestseller," Roger Allen ("Fiction and Publics") nominates three novels ${ }^{1}$ from different parts of the Arabic-speaking world which "have met decidedly mixed evaluative receptions from their local critical communities, and yet, in spite of that, have sold unusually large numbers of copies. Beyond that, their translated versions have also sold extremely well in Western markets" (10). The approach toward translation can itself have a significant bearing depending on how it is viewed: whether it is of the kind that domesticates and smoothes out the not easily translatable features of the Arabic original, or maintains by various stratagems the difference of Arabic texts with the aim of challenging the reader of the target culture (Venuti). In Allen's opinion it is significant that while each of these works adopts

very different narrative approaches, [they] are united in their avoidance of the ambiguity, uncertainty, and stylistic and generic complexity that is characteristic of much recent novelistic production in Arabic, and at the hands of writers as varied as Ilyas Khuri, Ibrahim Nasrallah, and Ibrahim al-Kuni. ("Fiction and Publics" 10)

Allen's observation begs the question as to what, beside their conventional narrative styles, these Arabic bestsellers have in common. We might argue that those writers who do succeed in getting translated and receive significant exposure may be said to comply, wittingly or not, with frequently rehearsed stereotypes about Arabs. ${ }^{2}$

Adopting the perspective of an American reader Steven Salaita suggests the "category of 'Arab' [...] brings to mind a set of images [...] some of them contradictory: brutish, misogynistic, untrustworthy, sexually voracious, greedy" (46). Drawing on an MLA survey that showed enrolment on Arabic literature courses in American universities rose significantly in the post 9/11 environment Sally Gomaa and Chad Raymond discuss a selection of texts placed on university syllabuses as representative of Arabic literature and culture. They argue that translated Arabic texts taught in an American classroom cover a limited repertoire and result in reinforcement of stereotypes of masculinity and violence. "Arabic fiction taught at undergraduate level in the US," they conclude, "does not reflect [...] an Arab world view as much as it reflects a neo-Orientalist vision of the Middle East, replete not with genies and flying carpets but with ominous, scheming jihadis and oppressed, exploited women" (39). It is quite thought provoking that Gomaa and Raymond signal out for discussion texts such as Tayeb Salih's Season of Migration to the North ("continues in the Orientalist tradition of exoticizing and sexualizing the Arab, Muslim, African male”); Alaa al-Aswany's Yacoubian Building ("Taha's story, albeit tragic, confirms stereotypical definitions of Arab masculinity"); Hanan al-Shaykh's Story of Zahra (foregrounds Arab society's "misogyny"); and Nawal El Saadawi's Woman at point Zero (quoting Christison: "El Saadawi has done irreparable harm to the Arab image in the West") $(33,34,35,38)$. All the writers/novels mentioned would presumably feature highly in a critical study of Arabic writing of the last fifty years. Perhaps the approach adopted by the authors of the article is itself somewhat naive and sensational and, rather than confirm the stereotypes they adduce, a sensi-

1. The three "Arabic bestsellers" Allen refers to are Rajaa Alsanea's Banat al-Riyad, Ahlam Mustaghanimi’s Dhakirat al-jasad, and Ala' al-Aswani, Imarat Ya'qubiyan

2. For modernist fiction and the reasons why it is unlikely to gain a wide readership in translation see Stefan Meyer and Fabio Caiani. 
tive and creative teacher could equally use some of the novels to challenge these. Nonetheless, it supports a key assumption that I wish to expand on: in the main, Western readers are acculturated to reproduction of a specific repertoire of representations and images of Arabs. To begin to address how this operates I shall start by reviewing critical work by specialists that probes how in a particular topic area translations into English significantly modify writing initially produced in a local national context.

\section{Translating Arab Women}

Hodda Elsadda writes: "the reception and consumption of Arab women's writing in translation in the West is inevitably tinted by the political and cultural environment of the host language" (xxviii). This state of affairs has been underlined in articles by Mohja Kahf and Amal Amireh in which they review translations of writings by two Arab women who have become feminist icons in the West. Kahf focuses on Margot Badran's translation and re-packaging of Huda Sha'rawi's memoirs for a Western audience, demonstrating how in the process of editing Badran seriously underplayed the public theatre of the Egyptian's activities in order to emphasise her secluded private world encapsulated in the word harem, which is almost entirely absent in the Arabic text. Amireh lays out disparities in respect of crucial terminology between Nawal El Saadawi's feminist-oriented work in Arabic and the widely read English versions. In both cases translation is shown to operate in such a way as to smooth over difference and situate the texts firmly within the Anglo-American reader's horizon of expectation. Kahf concludes that:

The United States reading public, despite promising instances here and there, takes in data about women from the Arab world mainly by using conventions emergent from a long history of Western stereotypes about the Arab peoples and the Islamic religion. I find that these conventions take shape today in three stereotypes about Arab women. One is that she is a victim of gender oppression; the second portrays her as an escapee of her intrinsically oppressive culture; and the third represents her as a pawn of Arab male power. (Kahf 285-86)

A more recent text that invites us to probe the extent to which identities are culturally stereotyped, resisted, overcome, or reproduced in translated literature is Rajaa Alsanea's novel Banat al-Riyadh. Entitled in its English version Girls of Riyadh this is a softer, less conflictual work than the translated Arabic novels mentioned above; it elicited highly positive reviews in the US and Britain on its publication in 2007. The novel's original translator Marilyn Booth in her article: "The Muslim Woman as Celebrity Author and the Politics of Translating Arabic: Girls of Riyadh Go on the Road" records how she strove to resist power differentials more urgently than the Arab author (and the western editors) who "wanted the book to blend in with the Anglophone popular fiction market which depends on familiar, at times formulaic, $[\ldots]$ structures and styles to maintain its large audience" (171). With respect to Girls of Riyadh Booth mobilizes familiar arguments pertaining to the Western publishing industry: powerful "multinational conglomerate media outlets" exerted pressures of domestication on the translated text erasing the Arabic version's many "cultural and linguistic specificities" thereby "assimilating the novel to the chick-lit generic conventions in the Anglophone market place" (149). The result, she claims, was that her well thought-out translation strategy to remain "closer to 
the original Arabic in reproducing (not omitting) lexica, modes of address, and genres of repartee" was sacrificed (174).

Not for want of trying on the part of the translator who was strongly minded to resist, in the case of Girls of Riyadh power differentials might seem to have won the day; the Arab author opted to work with the Western publisher to ensure accommodations were made. An author of a work of Arabic fiction, eager to establish its place in the world, specifically the Anglophone popular fiction market, Alsanea preferred to see through to publication a reader-friendly translation of her own text. In proffering an alternative translation, which she claims was closer to the original, Booth's intervention complicates the proposition that power differentials work more negatively on translated texts than on those composed directly in a metropolitan Western language. However, while the published English version may be said to confirm rather than challenge the reader's cultural expectations, it can be argued that in the case of Girls of Riyadh the writer was exercising her right of agency in approving such a translation; in desiring to render one she considered more "authentic" Booth's resistance could be seen as misplaced.

Moreover, the values projected by the novel in its Arabic original are not significantly changed in English translation. The setting with its ubiquitous cell phones, social media and shopping malls, above all the chick-lit genre of the novel, demonstrate the extent to which the local/national context has been transformed wholesale by the international and transnational. Girls of Riyadh on its own may not prove a thesis in respect of translations accommodating to power differentials. However, whatever its reception in the Arab world, its subject designates Alsanea's novel as prime for translation into English. We could say that the projection of the twentieth-first century behaviours and lifestyles of young Saudi women, sandwiched as they appear to be between the confinement of the same-sex extended harem and the postmodern freedoms of young Bridget Joneses, induces a pleasurable frisson in Western readers. What is new about these females is that they strain to enact agency as well as desire, only for the limitations of their society to rein them in. Simulacra of liberated Western "chicks," but imperfect ones, they remain at the mercy of deceitful Arab men who through perfidious manoeuvres such as breaking engagements, the arbitrary ending of relationships, or giving in to family pressures, can still ruin their happiness or destroy their reputations. A flavour of the impact the novel had on Western readers might be observed in the following extract from an online blog:

Although I am well versed with Arab culture, there are still shocking discoveries about the Saudi Arabian society. The novel is illuminating, it tells us of the reality of Saudi Arabian society. In Saudi Arabia, single young men are not allowed to enter certain famous shopping malls to avoid the harassment and flirting they initiate towards women. Valentine's day is banned because it is a Christian event that ignited unvirtuous feelings between boys and girls. ("bibliojunckie"; emphasis added)

The blogger, who claims to be "well versed with Arab culture," is gratified by the manner in which the text uploads information about peculiarities of Saudi society such as the use of Bedouin names and its main tribal divisions, in effect endorsing the text as authoritative ethnographic report. In addition he clearly approves the text's titillating revelations on aspects of gender separation, which we sense confirmed rather than shocked his expectations. 


\section{The Gender Pact}

I now wish to move on to discussion of the issue of how critical thinking has engaged with an alternative means of encoding Arab themes in literature: Anglo- (or Anglophone) Arab writing. Comparison of novels written in Arabic and translated into English, and novels written directly in English invokes variant sets of criteria while, I shall argue, still retaining significant commonalities. Obviously, there are differences in implied readership between novels written in Arabic and Anglophone Arab novels. Indeed it could be argued that the specific power differential is not necessarily a key concern for authors writing for a readership in the Arab world; for them power constraining their writing might be said to have a different application. Censorship is usually operative, and in the case of Egypt for example, as already discussed by Naaman above, a state-run writers' apparatus controls writers' publication opportunities. When it comes, however, to work taken up for a Western market, we have already touched on features that are lost in the translation process and others which favour the selection of texts for translation and circulation in the Anglophone world.

Additionally, when it comes to Anglophone Arab writing, we might consider what features are changed or receive undue emphasis, and which new ones are inscribed. In comparison with English translations of Arabic texts primarily concerned with representation of Arab women such as those discussed above, Anglophone Arab women's writing obviously works within different parameters. Accommodation to Western readers' horizon of expectation often seems less straight forward because it operates behind an exterior that appears to give agency to women writers. Freedom from censorship and publication in European languages provides the licence to explore patterns of behaviour only partially allowed to male Arab authors in Arabic, but not at all to female ones. The implication is that Arab women writers who can compose in European languages are doubly compensated for the lacks they face in their native land: in "exile" they gain the freedom to engage with behaviours interdicted by patriarchal societies as well as the licence to write about them. In fact Western publishers might be said to contract a pact with such authors that underwrites much of their work: in order to be published, this type of subject matter will form at least a part, if not the sum, of what they write. This can be said to spill over into gender issues relating to the fictional representation of Arab women not infrequently within cross-cultural relationships. This can be considered to be applicable for several writers discussed below.

If this is an accurate encapsulation of a significant range of Anglophone Arab women's writing the nostrum that a bilingual/Anglophone writer engaged in cultural translational fiction may be more aware of and motivated to resist power differentials needs to be problematised. Here, we should acknowledge a distinction between immigrant writers and writers born in the UK and the US where there is a different relationship to the colonial history. Discussing respectively novels by Egyptian-born Anglophone author Ahdaf Soueif and native Arab American writer Diana Abu-Jaber I shall nevertheless endeavour to show that similar imperatives apply. Soueif's fiction has been celebrated for its incorporation of an Arab national narrative and mildly deprecated (more in her earlier work) for recycling Orientalist tropes. In Immigrant Narratives Wail Hassan posits her novel Map of Love as "a paradigmatic text for what I have called 'translational literature" in a resistant mode (160). Other critics have also seen her work as a definitive, postcolonial Arab voice responding to British colonial influence in Egypt and the 
wider Arab world (164). Canadian-Iraqi academic Amin Malak has likewise celebrated her postcolonial vision, praising Soueif for her transposition of Egyptian dialect into an Arabised form of English and considering her attitude to one of her hybridised Egyptian protagonists as Rushdiesque (133). In her first novel, the semi-autobiographical Bildungsroman In the Eye of the Sun (1992), alongside a personal narrative focalizing her female protagonist Asya, Soueif attempts to deliver an Arab national perspective with mixed results as far as the coherence of the work is concerned. Her achievement might be said to reside in the novel's presentation of an Arab narrative filiated to the type of secular nationalism favoured by a significant number of intellectuals from the later twentieth/early twenty-first century Arab world, some of whom see her fiction as in part owing its provenance to Naguib Mahfuz and Tayeb Salih, or even as incorporating Edward Said's case against Orientalism (King). For these, we could argue, the nationalist element acts as a benchmark against which the resistance quality of Soueif's particular brand of Anglophone Arab writing is to be measured.

From the beginning of her career as an Anglophone Arab writer in the 1980s, however, Soueif has also attracted criticism for employing Orientalist tropes, particularly in her representation of Arab female sexuality. Asya of In the Eye of the Sun is summarised by Joseph Massad as motivated by a "quest to combine love and desire" (Massad 76). Her much discussed relationship with the English hippy Gerald demonstrates a curious "presentation of Egypt or the East in terms that perhaps the West was comfortable with," and of upper "class Orientalism" (Massad 86; Hassan, 2011: 162). It might be useful here to draw parallels between Soueif's novel and Assia Djebar's Les Enfants du nowveau monde (1962), which in certain respects Soueif's shadows. Both novels engage with colonial/post-colonial struggles (in Soueif's the Arab-Israeli war of June 1967) that provide backdrops to the respective young female protagonists' pursuit of a lifestyle of experimentation beyond the expectation of their female compatriots. Soueif's novel might be considered to wander into the territory of Kahf's three stereotypes about Arab women with Asya an escapee from "intrinsically oppressive" Egyptian culture where fathers must sanction their daughters' behaviours and male doctors have the licence to linger over inspection of their female patients' genitalia. Soueif's Arab female character escapee lapses into a tortuous cross-cultural relationship: in an intriguing reversal Asya becomes victim to gender oppression not by a manipulative Arab male but an exploitative Orientalising English one. Certainly Soueif realised the undesirability of In the Eye of the Sun being translated into Arabic, partly no doubt on account of women's writing tendency to be received as autobiography in the Middle East.

The events in Diana Abu-Jaber's second novel Crescent are transacted in a milieu in which Middle East immigrants are numerous, but the narrative is focalized through Syrine, an American-born young woman of mixed Arab/Irish ethnicity. The work has been celebrated for its weaving into a Californian setting different strands of Arab and Middle Eastern ethnicity to produce a sort of revived "Andalusian legacy" or convivencia. In Nadia's café Arab American Syrine, through a variety of styles of Arab cooking brings together exiles from different Arab countries and native-born Americans of Arab ethnicity against the chauvinistic backdrop to the invasion of Iraq in 2003. The Pan-Arab politico-cultural mix, in this case not limited to the Anglo-Egyptian-Palestinian triangle of Soueif's writing, has inspired Nouri Gana to laud the novel for 
drawing a complex tableau of Arab American subjectivities - attending thereby to their daily lives, traumata, and joys, and harnessing their histories and aspiration with those of multiple other ethnicities. The ultimate effect is the demystification of the Middle Eastern politics and reconfiguration of Arabness through a retrospective reactivation of Andalusian conviviality. (206)

However, in spite of its achievement in representing an Arab politics within an American context, Abu Jaber's work also re-iterates Orientalist tropes concerning incarceration, male-honour chauvinism and veiling. As a counterpoint to American fixation on terror, incidents in the novel disclose a brooding sexually-driven violence and violation either visited by or on Arabs. On the personal front, the female characters deliver testimonios on Arab boyfriends/husbands. Syrine's narrative of her boyfriend Han's Othellotype jealousy over a scarf he gives her and she loses takes the reader into the territory of the Arabic fiction stereotypes discussed by Gomaa and Raymond. Saudi Arabian student Rana fills the escapee role to a tee; having succeeded in releasing herself from the imprisonment meted upon her by her obsessive "control freak" Saudi husband she comes to university in America where, while still wearing full Islamic dress, she engages in a succession of casual sexual encounters. Rana admits she is not eager to relate her story to her American friends because "it just feeds all the stereotypes," (270) and while Abu-Jaber's defence here could be that she is attempting to modify these, in the process of repetition she also appears to be reinforcing them (Aldalala'a and Nash).

What is particularly of interest in comparing these two novels, aside from their variant articulations of the politics of Arab/West contestation and their different focalizations of home and of foreignness, is the degree to which each allows entry to the kind of stereotypical representations of Arab women that conform to what Kahf, quoting Wolfgang Iser, terms Western "reader expectation." In her closing remarks she goes on to argue: "This calls for texts that make reading less smooth. It calls for publishers, translators, authors, and readers to become conscious of comfortable patterns of reception of the sort that restrict Arab women's writing to the ghetto of victims, escapees and pawns" (302).

I am aware that this statement is made in reference to Sha'rawi's Arabic memoir and its English translation, and therefore that I might be charged with conflating Anglophone Arab writing and translation in a way unwarranted by Kahf's remarks. Yet I do not consider this is stretching the significance of the encodings of women's experience, which I have been discussing so far. Despite their outward enfranchisement by leaving the Arab homeland for the West in the Anglophone text, we might say that Arab women, in their fictions, are still victims and escapees, only functioning on a broader stage. The feature of cross-cultural sexual encounter that Soueif introduces in In the Eye of the Sun and continues in Map of Love (in the case of the latter it may well have been borrowed from one of its intertexts, Ruth Prawer Jhabvala's Heat and Dust) becomes almost a staple of Arab women's Anglophone fiction. The mode most frequently adopted is the Arab female/Western male alliance which is also found in, for example, Fadia Faqir's My Name is Salma and in Hanan al-Shaykh's bilingual Only in London. It doesn't stretch our imagination too far to see such cases as romantic updates of Spivak's celebrated nostrum of white men saving brown women from brown men. 


\section{Cultural Translation and Anglophone Arab Fiction: The Facility to Resist Power Differentials?}

The proposition that there is such a thing as "a gender pact" between Western publishers, and authors and translators of a certain genre of Arab women's writing, is part of my argument that Arabic novels translated into English, and those written directly in English, frequently invoke a set of criteria which retain commonalities pertaining to Western reader expectation and the representation of Arab women. This position, I shall now go on to argue, is not significantly diminished by the notion that as a type of cultural translation, Anglophone Arab writing is better situated than translation to resist such stereotypical formulation.

Edward Said was perhaps the first to celebrate the sexual politics of Soueif's work and there can be little doubt that alongside other Arab feminist writers like Fadia Faqir, she stages an obvious challenge to conservative mores as related to the treatment of women in Arab societies. On the reaction in Egypt to the Arabic translation of Map of Love Wail Hassan points out:

Those defensive [Egyptian/Arab] readers who accused Soueif of defamation saw no difference between an Egyptian author of a controversial English book and a hostile European writer. Interestingly, some who defended Soueif did so based on the fact that the novel was written in English, so in both camps, the politics of language and location was paramount. (Immigrant Narratives 166)

Addressing whether or not this is an issue of "two-way cultural translation" proving impossible, Hassan significantly points out Soueif's "success has to a great extent been due to her location and her translational use of English" (Immigrant Narratives 166). In his analysis of Anglophone Arab writing Hassan applies the term "translational literature" to "those texts that straddle two languages, at once foregrounding, performing, and problematising the act of translation" (Immigrant Narratives 32). Here Hassan can be said to have progressed Lawrence Venuti's concept of foreignisation by stretching it to incorporate texts by Arab writers composed in a language other than Arabic, in for example Hebrew and French as well as English. Hassan proposes that certain Anglophone texts constitute a form of writing that can "thematize the processes of translation," "bring into sharp relief the conditions of immigrant Arab writing in general and draw a benchmark for the most contestatory kinds of cultural translation found in it." This, type of literature, he argues:

offer[s] the most radical form of cultural translation [...][because it] lay[s] special emphasis on translation as a crucial component of cross-cultural contact [...] More crucially, translational texts are positioned to resist power differentials that influence the work of the translator and reproduce stereotyped cultural identities (33; emphasis added)

Hassan proceeds to list a variety of strategies adopted in translational texts, from transliterating words and phrases for which there is no English equivalent to inserting literal translation of idiomatic expressions, all of which together have as their product the facility to “Arabize,' 'Africanize,' or 'Indianize' English" (“Agency and Translational Literature" 754). In point of fact Anglophone Arab writers who create this form of literature are not necessarily performing anything new as Hassan recognizes by referencing African and Indian writers who do the same thing as well as Maghrebians who write in French. However a bilingual writer, it is implied, might be more enabled and better 
placed to engage in resistance to power differentials than a writer, and perhaps more crucially a translator of Arabic fiction. While this may well be the case, the assumption, vis-à-vis translation of Arabic fiction in particular, is that producers of Anglophone translational fiction potentially may be more aware of and more motivated to resist the power differentials implicit in translated text.

There is, however, a corollary, one connecting both Arabic literary works translated into English, and Anglophone Arab fiction: that is, a translator from Arabic into English and an Anglophone writer are equally at liberty to take up the option either of accommodating or of resisting power differentials. Either may accede to the pressures of market demand and the literary conventions of English fiction if they are so inclined. To state this corollary is not, however, to confuse the imbalance in cultural translation where, as we have already argued, the pressure to accommodate to the target culture can be stronger than the pressure to resist. In the case of the translator there may be little reason to adopt a foreignising stance, especially since, as Aboul-Ela argues, publishers prefer ones who have English as their first language. However, in the case of cultural translation, as Susan Bassnett notes, "the use of translation as a figurative term to explore postcolonial contexts has not found universal acceptance" (344). Some critics have a priori problems with cultural translation's underpinning. In particular, Bassnett cites Harish Trivedi who has argued against it on the grounds that it "focuses on the idea of exchange, not the reality of the language contact" (344). Though she considers Trivedi's position "harsh," Bassnett has sympathy with his view that cultural translation marginalises interlingual translation ("translation between languages") through "the appropriation of a discourse of translation by scholars who are unable to translate because they can only function in a single language" (344). Egyptian novelist and critic Samia Serageldin also calls into question the kind of Anglophone writers who would need to write in English because that is their "only language of written expression" (436). In the Indian context at least, Trivedi contends such a state of affairs disadvantages "minority" languages (344). To dismiss this position as a species of nativism may be too easy: to do so might well be said to cover a contested element in the postcolonial project itself. That is, the charge that the cosmopolitan sites of enunciation out of which postcolonial writers and critics work can lead to shortchanging of the cultures on which they purport to discourse. Trivedi's reaction can be extended to Arabic-speaking critics who according to Mara Namaan contend that postcolonial approaches to reading literature replace "indigenous cultural field[s]" which are not addressed to a privileged global or cosmopolitan reader ${ }^{3}$ (463). In both contexts there appears to be support for Trivedi's argument that "those of us still located on our home turf and in our own cultures and speaking our own languages can no longer be seen or heard” (qtd. in Bassnett 344).

\section{Conclusion}

Clearly, whether Arabs write novels in Arabic, either with the intention or the effect of their being translated into English, or attempt to incorporate Arab meanings into fiction

3. Postcolonial criticism of Arabic literature has been no more able to throw off a westocentric vantage point than the conventional criticism, which has been inscribed in Western terms, with importation of terminology derived from periodicity applied to Western literatures. Also, within the national canon, debate over what was the first Arabic novel was "regulated by the symbolic of a [Western-oriented] liberal national elite whose cultural imaginary shaped the literary canon so as to represent their own worldviews and their ontological and dominion" (Elsadda xxi). 
by composing directly into a language that can command a global readership, what they produce will necessarily be modified from what is produced in a local, national context. Such an assessment is hardly controversial. That there will be considerable difference in the way novels written in Arabic signify for an Arab readership, and those either translated into or directly composed in English signify to an international readership almost goes without saying. My focus has largely excluded the majority of Arabic literary texts, which remain untranslated, as well as the few texts which tend to be modernist or experimental in certain aspects and which are translated for their perceived literary merit but which will not gain a wide readership in translation. The proposition that some Anglophone Arab novels (Arab American or Arab British), particularly the type addressed to the experience of Arab women, in enacting the function of cultural translation have the capacity and scope to circumvent the translator's bias and undermine neo-colonial/ Orientalist stereotyping of Arabs and Islam, can not be considered a straightforward assumption. Arab Anglophone writing may be better positioned to resist the power differentials that influence the work of the translator and reproduce stereotyped cultural identities, but in practice this advantage is not pressed home unreservedly. On the contrary, restrictions can be considered significant enough to undermine the premise. Anglophone writing's privileged enterprise as cultural translation is called into question in the case of the kind of English composition that not only could not have been encoded in Arabic, but follows a tacit set of rules whereby the culture leaving its traces on the protagonist, or otherwise reported on, is implicitly marked backward and inferior. In the words of Samia Serageldin: "The successes of these novels in English by authors of Middle Eastern heritage highlights, conversely, that their target audience is limited to the Western reader. They may bring the East to the West, but they often do not travel well in the opposite direction" (435). In this article I have attempted to problematise the notion that Anglophone Arab writing offers a corrective to the semantic failings of the genre of commercially successful Arabic literature in English translation. Western publishers may favour the incorporation of specific exotic or sensational tropes in translated Arabic fiction, as well as encourage similar features in Anglophone writing by writers of Arab ethnicity. The claim that Anglophone Arab novels, as a form of postcolonial writing, possess both the potential and the achievement of circumventing translational bias and undermining stereotyping of Arabs and Islam can receive at best only qualified assent. The notion that because they are better set up to resist such stereotyping they are more effective is not conclusively borne out by the evidence.

Geoffrey NaSH

The University of Sunderland (United Kingdom)

\section{Works Cited}

Aboul-Ela, Hosam. "Challenging the Embargo.” Middle East Report 219 (2001): $42-44$.

Abu-Jabber, Diana. Crescent. London: Picador, 2003.

Aldalala'A, Nath and Geoffrey Nash. "Coming out for Islam? Critical Muslim Responses to Postcolonialism in Theory and Writing." Islam and Postcolonial Discourse: Purity and Hybridity. Ed. Esra Mirze Santesso and James McClung. London: Routledge, 2017.

Alden, Roger. "The Happy Traitor: Tales of Translation." Comparative Literature Studies 47.4 (2010): 472-86. 
—. "Fiction and Publics: The Emergence of the 'Arabic Best-Seller'." The State of the Arts in the Middle East: Viempoints Special Edition. The Middle East Institute Washington D.C.: 9-12. Nd. 6 November 2016 < http://www.mei.edu/sites/default/files/publications/state-arts-middle-east.pdf>.

AmireH, Amal. "Framing Nawal El Sadaawi: Arab Feminism in a Transnational World." Intersections: Gender, Nation and Community in Arab Women's Novels. Ed. Lisa Suhair Mahjah, Paula W. Sunderman, and Therese Salibi. New York: Syracuse UP, 2001. 33-67.

Bassnetr, Susan. "Postcolonial and/as Translation." The Oxford Handbook of Postcolonial Studies. Ed. Graham Huggan. Oxford: Oxford UP. 340-358.

Bibliojunkie. "Girls of Riyadh." 9 June 2009. 31 May 2016 <https://bibliojunkie.wordpress. com/2009/06/09/girls-of-riyadh>.

Bоотн, Marilyn. "The Muslim Woman as Celebrity Author and the Politics of Translating Arabic: Girls of Riyadh Go on the Road." Journal of Middle East Women's Studies 6.3 (2010): 149-182.

Cainno, Fabio. Contemporary Arab Fiction: Innovation from Rama to Yalu. London: Routledge, 2007.

ElsadDa, Hoda. Gender, Nation and the Arabic Novel: Egypt, 1892-2008. Edinburgh: Edinburgh U P, 2014.

Djebar, Assia. Children of the New World: A Novel of the Algerian War. 1962. Trans. Marjolijn de Jager. New York: Feminist P at the City of New York, 2005.

GanA, Nouri. "In Search of Andalusia: Reconfiguring Arabness in Diana Abu-Jaber's Crescent." The Edinburgh Companion to the Arab Novel in English: The Politics of Arab American Literature and Culture. Ed. Nouri Gana. Edinburgh: Edinburgh UP, 2013. 197-216.

GomaA, Sally and Chad Raymond. "Lost in Non-Translation: the Politics of Misrepresenting Arabs." Arab Studies Quarterly 36.1 (2014): 27-42.

Hassan, Wail S. "Agency and Translational Literature: Ahdaf Soueif's The Map of Love." The Modern Language Association of America 121.3 (2006): 753-68.

-. Immigrant Narratives: Orientalism and Cultural Translation in Arab American and Arab British Literature. New York: Oxford UP, 2011.

KaHF, Mohja. "Packaging 'Huda': Sha'rawi's Memoirs in the United States Reception Environment." Translation Studies: Critical Concepts in Linguistics 2. Ed. Mona Baker. London: Routledge, 2009. 285306.

KING, Katherine Callen. "Translating Heroism: Locating Edward Said on Ahdaf Soueif's The Map of Love." Edward Said: A Legacy of Emancipation and Representation. Ed. Adel Iskandar and Hakem Rustom. Berkeley: U of California P, 2010. 142-58.

MaLak, Amin. Muslim Narratives and the Discourse of English. Albany: SUNY P, 2005.

MAssaD, Joseph. "The Politics of Desire in the Writings of Ahdaf Soueif." Journal of Palestine Studies 28.4 (1999): 74-90.

Meyer, Stephen. The Experimental Arabic Novel: Postcolonial Literary Modernism in the Levant. Syracuse, NY: SUNY P, 2001.

NaAman, Mara. "Disciplining Divergencies: Problematizing the Field of Arabic Literature." Comparative Literature Studies 47.4 (2010): 446-71.

SAID, Edward W. "Embargoed Literature." The Nation, 17 Sept. 1990.

SalAita, Steven. Modern Arabic Fiction: A Reader's Guide. Syracuse, NY: Syracuse UP, 2011.

Serageldin, Samia. "Perils and Pitfalls of Marketing the Arab Novel in English." The Edinburgh Companion to the Arab Novel in English: The Politics of Arab American Literature and Culture. Ed. Nouri Gana. Edinburgh: Edinburgh UP, 2013. 426-46.

Shamma, Tarek, ed. Current Call for Papers. "Arabic Literature in Translation: Politics and Poetics." Clina: An Interdisciplinary Journal of Translation, Interpreting, and Intercultual Communication, 2016. 6 May 2016 < http:/ / diarium.usal.es/revistaclina/home/call-for-papers>.

SOUEIF, Ahdaf. In the Eye of the Sun. London: Bloomsbury, 1992.

Venuti, Lawrence. The Translator's Invisibility: A History of Translation. London: Routledge, 1995. 